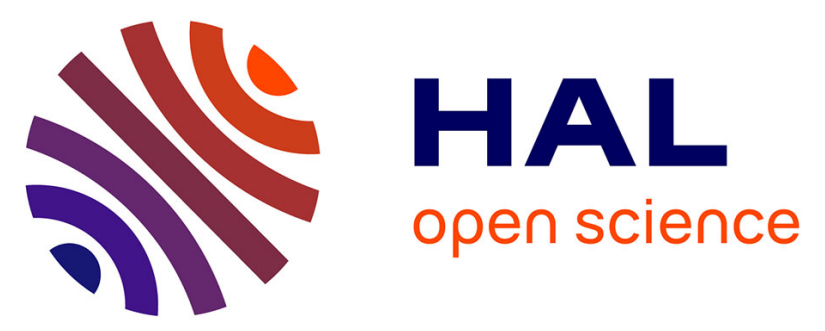

\title{
Dermal absorption of semivolatile organic compounds from the gas phase: Sensitivity of exposure assessment by steady state modeling to key parameters
}

Maud Pelletier, Nathalie Bonvallot, Olivier Ramalho, Olivier Blanchard, Corinne Mandin, Barbara Le Bot, Fabien Mercier, Philippe Glorennec

\section{To cite this version:}

Maud Pelletier, Nathalie Bonvallot, Olivier Ramalho, Olivier Blanchard, Corinne Mandin, et al.. Dermal absorption of semivolatile organic compounds from the gas phase: Sensitivity of exposure assessment by steady state modeling to key parameters. Environment International, 2017, 102, pp.106113. 10.1016/j.envint.2017.02.005 . hal-01635769

\section{HAL Id: hal-01635769 https://hal.science/hal-01635769}

Submitted on 15 Nov 2017

HAL is a multi-disciplinary open access archive for the deposit and dissemination of scientific research documents, whether they are published or not. The documents may come from teaching and research institutions in France or abroad, or from public or private research centers.
L'archive ouverte pluridisciplinaire HAL, est destinée au dépôt et à la diffusion de documents scientifiques de niveau recherche, publiés ou non, émanant des établissements d'enseignement et de recherche français ou étrangers, des laboratoires publics ou privés. 


\section{Dermal absorption of semivolatile organic compounds from the gas phase: sensitivity of}

exposure assessment by steady state modeling to key parameters

Maud Pelletier ${ }^{1,2}$, Nathalie Bonvallot ${ }^{1,2}$, Olivier Ramalho ${ }^{3}$, Olivier Blanchard ${ }^{1,2}$, Fabien

5

\section{${ }^{1}$ EHESP-School of Public Health, Sorbonne Paris Cité, Rennes, France}

${ }^{2}$ INSERM-U1085, Irset-Research Institute for Environmental and Occupational Health, Rennes, France

${ }^{3}$ University of Paris-Est, Scientific and Technical Center for Building (CSTB), Health and Comfort Department, French Indoor Air Quality Observatory (OQAI), 84 Avenue Jean Jaurès, Champs sur Marne, 77447 Marne la Vallée Cedex 2, France

${ }^{4}$ LERES-Environment and Health Research Laboratory (Irset and EHESP Technologic Platform), Rennes, France

*Corresponding author:

INSERM-U1085, Irset-Research Institute for Environmental and Occupational Health, Rennes, France. EHESP-School of Public Health, Sorbonne Paris Cité, Rennes, France.

Tel.: +33-2 99022680 .

E-mail address: philippe.glorennec@ehesp.fr 


\section{ABSTRACT}

Recent research has demonstrated the importance of dermal exposure for some semivolatile organic compounds (SVOCs) present in the gas phase of indoor air. Though models for estimating dermal intake from gaseous SVOCs exist, their predictions can be subject to variations in input parameters, which can lead to large variation in exposure estimations. In this sensitivity analysis for a steady state model, we aimed to assess these variations and their determinants using probabilistic Monte Carlo sampling for 8 SVOCs from different chemical families: phthalates, bisphenols, polycyclic aromatic hydrocarbons (PAHs), organophosphorus (OPs), organochlorines (OCs), synthetic musks, polychlorinated biphenyls (PCBs) and polybromodiphenylethers (PBDEs). Indoor SVOC concentrations were found to be the most influential parameters. Both Henry's law constant $(\mathrm{H})$ and octanol/water partition coefficient $\left(\mathrm{K}_{\mathrm{ow}}\right)$ uncertainty also had significant influence. While exposure media properties such as volume fraction of organic matter in the particle phase $\left(f_{\text {om-part }}\right)$, particle density $\left(\rho_{\text {part }}\right)$, concentration ([TSP]) and transport coefficient $\left(\mathrm{\gamma}_{\mathrm{d}}\right)$ had a slight influence for some compounds, human parameters such as body weight (W), body surface area (A) and daily exposure (t) make a marginal or null contribution to the variance of dermal intake for a given age group. Inclusion of a parameter sensitivity analysis appears essential to reporting uncertainties in dermal exposure assessment.

\section{KEY WORDS}

Percutaneous, indoor air, chemical, contact, sensitivity analysis, Monte Carlo.

\section{HIGHLIGHTS}

- $\quad$ Sensitivity analysis was conducted for 8 SVOCs with MC simulations.

- $\quad$ SVOC air concentration is the most influential variable parameter. 
- Octanol-water partition coefficient and Henry's law constant are influent uncertain

52

MW SVOC molecular weight $(\mathrm{g} / \mathrm{mol})$

62 parameters.
ABBREVIATIONS

A Body surface area $\left(\mathrm{m}^{2}\right)$ of body weight per day, $\mu \mathrm{g} / \mathrm{kg}-\mathrm{bw} / \mathrm{d}$ )

$H \quad$ Henry’s law constant $\left(\mathrm{Pa} . \mathrm{m}^{3} / \mathrm{mol}\right)$

$K_{o a} \quad$ Octanol/air partition coefficient

$K_{\text {ow }} \quad$ Octanol/water partition coefficient

$P_{s} \quad$ SVOC vapor pressure $(\mathrm{Pa})$

- Influence of airborne particles characteristics and human parameters is minimal.

$C_{a} \quad$ SVOC total concentration in indoor air $\left(\mathrm{C}_{\mathrm{g}}+\mathrm{F}\right)\left(\mathrm{ng} / \mathrm{m}^{3}\right)$

$C_{g} \quad$ SVOC concentration in the gas phase $\left(\mathrm{ng} / \mathrm{m}^{3}\right)$

$D I_{\text {dermal-gas }}$ Daily intake by dermal exposure through the gas phase (micrograms per kilogram

F $\quad$ SVOC concentration in the particulate phase $\left(\mathrm{ng} / \mathrm{m}^{3}\right.$ of air)

$f_{\text {om-part }}$ Volume fraction of organic matter associated with airborne particles

$K_{p} \quad$ Gas/particle distribution coefficient $\left(\mathrm{m}^{3} / \mu \mathrm{g}\right)$

$k_{p g} \quad$ Indoor air transdermal permeability coefficient, describing the transport of a gas phase SVOC from bulk indoor air to dermal capillaries, through the boundary layer adjacent to skin, the stratum corneum and viable epidermis composite $(\mathrm{m} / \mathrm{h})$ 
63 $R \quad$ Ideal gas constant (=8.314 $\left.\mathrm{Pa} . \mathrm{m}^{3} / \mathrm{mol} . \mathrm{K}\right)$

64 $\rho_{\text {part }} \quad$ Density of airborne particles $\left(\mathrm{g} / \mathrm{m}^{3}\right)$

65 66

SVOC Semivolatile organic compound

$t \quad$ Daily exposure duration (h/d)

$T \quad$ Temperature (K)

[TSP] Total suspended particle concentration $\left(\mu \mathrm{g} / \mathrm{m}^{3}\right)$

W Body weight $(\mathrm{kg})$

\section{INTRODUCTION}

$\gamma_{d} \quad$ Coefficient describing the external transport of a gas phase SVOC from the bulk indoor air to the boundary layer adjacent to the skin $(\mathrm{m} / \mathrm{h})$

People spend more than $80 \%$ of their time in enclosed spaces, largely in dwellings in which they are exposed to an increasing number of chemicals from various sources and via different exposure routes. In addition to other pollutants found in indoor environments (radon, carbon monoxide, formaldehyde and other volatile organic compounds), semivolatile organic compounds (SVOCs) have received a great deal of attention, due to a rise in their use in consumer products as well as improved analytical techniques that have shown their ubiquity in dwellings (Rudel et al., 2003; Weschler and Nazaroff, 2008).

SVOCs include organic molecules from many different chemical families (phthalates, bisphenols, polycyclic aromatic hydrocarbons (PAHs), organophosphorus (OPs), organochlorines (OCs), synthetic musks, polychlorinated biphenyls (PCBs), polybromodiphenylethers (PBDEs), etc.). They are emitted from multiple household sources: flooring and wall materials, furniture, cosmetics, cleaning products, combustion products, 
packaging, etc. Due to their physical-chemical properties, they are able to migrate to, and partition between, different indoor compartments, including gas phase and airborne particles and settled dust (Weschler and Nazaroff, 2008), as well as other available surfaces such as walls, ceiling and flooring materials - or human skin and clothing. The scientific community's growing interest in studying exposure to these compounds is motivated by suspicion of reprotoxic, (Rubin, 2011; Moreau-Guigon and Chevreuil, 2014), neurotoxic (Baldi et al., 2001; Elbaz et al., 2009; Blanc-Lapierre et al., 2012; Zaganas et al., 2013) and carcinogenic (Armstrong et al., 2004; IARC, 2010a, 2010b) health effects, as well as the acknowledged presence of these compounds and their metabolites in human biological fluids (blood and urine) (NHANES, 2015). This interest is even more pronounced with regard to pregnant women and young children, considered more sensitive to these toxic effects (Grandjean et al., 2008).

At home, in addition to food ingestion (the main exposure pathway for many SVOCs), people are exposed through a variety of pathways: direct contact with the SVOC source, inhalation and contact with indoor air (gaseous and particulate phases), ingestion and contact with settled dust (on floor and furniture). Young children are more exposed than the rest of the population due to their more frequent contact with the ground and deposited dust, carrying objects in their mouths, etc. Though dust ingestion and inhalation of gaseous and particulate phases are the two best-documented exposure pathways in the literature, dermal absorption is rarely assessed in the course of environmental exposure assessments, because it is presumed to be negligible. Nevertheless, recent research has hypothesized the significance of dermal exposure (Weschler and Nazaroff, 2012; Gong et al. 2014) and more recently Weschler et al. (2015) and Morrison et al. (2016) have corroborated these findings via experimental human dermal exposure to two gaseous phthalates: diethyl phthalate (DEP) and di-n-butyl phthalate (DnBP). The results confirm that transdermal uptake directly from air can be a meaningful 
exposure pathway for DEP and DnBP, and that direct dermal absorption from air is also expected to be significant for other SVOCs, where the molecular weight and $\mathrm{K}_{\mathrm{ow}}$ are in a similar range. Bekö et al. (2013) estimated daily intakes resulting from four different indoor exposure pathways: dust ingestion, inhalation and dermal exposure through gas phase and through dust adhering to skin, based on phthalates' metabolites levels in urine samples of DEP, DnBP, di(isobutyl) phthalate (DiBP), butyl benzyl phthalate (BBzP) and di(2ethylhexyl) phthalate (DEHP) and their concentration in dust samples collected at the same time. They found that gas phase dermal absorption was the major exposure pathway for the more volatile compounds, in comparison with the other pathways involved. They also found that intake through dermal contact with dust contributed only very slightly to total intake for all studied phthalates. In order to assess SVOC gas phase dermal exposure, some authors have adapted and used a model based on mass-transfer resistance to calculate an indoor air transdermal permeability coefficient $\mathrm{k}_{\mathrm{p}-\mathrm{g}}$ (Weschler and Nazaroff, 2012; Bekö et al., 2013). This mass-transfer model describes the transport of a gas phase SVOC from bulk indoor air to dermal capillaries, through the boundary layer adjacent to skin, the stratum corneum and the viable epidermis composite.

At equilibrium and due to their physical-chemical properties, especially $\mathrm{K}_{\mathrm{oa}}$, SVOCs partition between the gas and particle phases of indoor air (Finizio et al., 1997; Pankow, 1998; Weschler and Nazaroff, 2008). When assessing gaseous SVOC dermal exposure, concentration in the gas phase $\left(\mathrm{C}_{\mathrm{g}}\right)$ is required and could be either measured or modeled from total concentration in indoor air $\left(\mathrm{C}_{\mathrm{a}}\right)$ - which is the sum of gas and particulate $(\mathrm{F})$ phases $\left(\mathrm{C}_{\mathrm{g}}+\mathrm{F}=\mathrm{C}_{\mathrm{a}}\right)$. Salthammer and Schripp (2015) have highlighted the importance of taking parameter uncertainty and variability into account when assessing SVOC partitioning and exposure. Weschler and Nazaroff (2014) have already assessed the sensitivity of $\mathrm{k}_{\mathrm{p}-\mathrm{g}}$ and other partitioning coefficient calculations, such as $\mathrm{K}_{\mathrm{p}}$, to the octanol/water partition 
coefficient $\left(\mathrm{K}_{\mathrm{ow}}\right)$, the octanol/air partition coefficient $\left(\mathrm{K}_{\mathrm{oa}}\right)$ and Henry's law constant $(\mathrm{H})$ uncertainties. We would like to continue this work here by evaluating the sensitivity of dermal intake, i.e. the mass of pollutant entering the body per $\mathrm{kg}$ of body weight and unit of time, to these parameters using a steady-state model.

The objective of this sensitivity analysis is to evaluate dermal intake variation caused by the uncertainty and variability of input parameters when using the model described by Weschler and Nazaroff (2012) for dermal absorption of gas phase SVOCs. We chose the study by Blanchard et al. (2014), in which 57 indoor SVOCs of health interest (Bonvallot et al., 2010) were measured with separation of their gas phase and airborne particle concentrations, as a starting study. We selected eight compounds from different chemical families having varied $\mathrm{K}_{\mathrm{oa}}$ and volatility to represent contrasting situations: dimethyl phthalate (DMP), phenanthrene, galaxolide (HHCB), PCB 105, diazinon, permethrin, bisphenol A (BPA) and BDE 154.

\section{METHODS}

1. Equation tested for dermal intake modeling

For a given human, chronic daily intake of gas phase SVOC via the dermal pathway, $\mathrm{DI}_{\text {dermal- }}$ gas, can be estimated in steady-state conditions using the following equation adapted by Bekö et al. (2013).

$$
D I_{\text {dermal-gas }}=\frac{\frac{C_{g} \times k_{p-g} \times A \times t}{1000}}{W}
$$

Where $C_{g}$ is the SVOC gas phase concentration $\left(\mathrm{ng} / \mathrm{m}^{3}\right), A$ is the body surface area $\left(\mathrm{m}^{2}\right), \mathrm{t}$ is the daily duration of exposure $(\mathrm{h} / \mathrm{d}), \mathrm{W}$ is the body weight $(\mathrm{kg}), \mathrm{k}_{\mathrm{p}-\mathrm{g}}$ is the SVOC transdermal permeability coefficient $(\mathrm{m} / \mathrm{h})$ and $\mathrm{DI}_{\text {dermal-gas }}$ is expressed in $\mu \mathrm{g} / \mathrm{kg}-\mathrm{bw} / \mathrm{d}$. 
157 The indoor air transdermal permeability coefficient $\left(\mathrm{k}_{\mathrm{p}-\mathrm{g}}\right)$ can be estimated using the steady-

158 state model adapted by Weschler and Nazaroff $(2012,2014)$, (see supplementary material for 159 the intermediate equations used to derive Equation 2):

$$
k_{p-g}=1 /\left(\frac{1}{\gamma_{d}}+\left(\frac{H}{R T} / \frac{10^{\left(0.7 \times \log \left(K_{o w}\right)-0.0722 \times M W^{2 / 3}-5.252\right)} \times 3600 \times 10^{-2}}{1+\left(10^{\left(0.7 \times \log \left(K_{o w}\right)-0.0722 \times M W^{2 / 3}-5.252\right)} \times M W^{0.5} \times 3600 / 2.6\right)}\right)\right)
$$

161 Where $\mathrm{K}_{\mathrm{ow}}$ is the SVOC octanol-water partition coefficient, MW is the SVOC molecular 162 weight $(\mathrm{g} / \mathrm{mol}), \mathrm{H}$ is the Henry's law constant $\left(\mathrm{Pa} . \mathrm{m}^{3} / \mathrm{mol}\right), \mathrm{R}$ is the ideal gas constant $(8.314$ $\left.163 \mathrm{~Pa} \cdot \mathrm{m}^{3} / \mathrm{mol} . \mathrm{K}\right), \mathrm{T}$ is the air temperature $(\mathrm{K})$ and $\mathrm{\gamma}_{\mathrm{d}}$ is the coefficient that describes the external transport of an SVOC from the gas phase in the core of a room through the boundary layer adjacent to the skin $(\mathrm{m} / \mathrm{h})$.

When estimating dermal intake from the gas phase (see Equations 1 and 2), exposure assessors may face two situations which can be distinguished in terms of availability of the $\mathrm{C}_{\mathrm{g}}$ value: A) $C_{g}$ is measured experimentally or B) $C_{g}$ is calculated from total indoor air concentration $\left(\mathrm{C}_{\mathrm{a}}\right)$. Assuming that SVOCs are in equilibrium between gas and particulate phases, $\mathrm{C}_{\mathrm{g}}$ can be estimated from $\mathrm{C}_{\mathrm{a}}$ using the partitioning model proposed by Weschler and Nazaroff (2010) and can be expressed as follows (see supplementary material for the detailed

172 calculation):

$$
C_{g}=\frac{C_{a}}{1+\left([T S P] \times \frac{f_{\text {om-part }} \times K_{o w} \times R \times T}{\rho_{\text {part }} \times 10^{6} \times H}\right)}
$$

174 Where [TSP] is the total suspended particle concentration $\left(\mu \mathrm{g} / \mathrm{m}^{3}\right), \mathrm{f}_{\text {om-part }}$ is the volume 175 fraction of organic matter associated with airborne particles and $\rho_{\text {part }}$ is the density of airborne 176 particles. 
The impact of uncertainty or variability of equation parameters on $\mathrm{DI}_{\text {dermal-gas }}$ variability was assessed. Parameter distributions were constructed or retrieved from the literature as detailed below. For a given group of occupants in a given indoor setting, some of these parameters will be the same for all SVOCs ( $\mathrm{y}_{\mathrm{d}},[\mathrm{TSP}], \mathrm{f}_{\mathrm{om}-\mathrm{part}}, \rho_{\text {part }}, \mathrm{W}, \mathrm{A}$ and $\mathrm{t}$ ) while others will vary from one compound to another $\left(\mathrm{K}_{\mathrm{ow}}, \mathrm{H}, \mathrm{C}_{\mathrm{g}}\right.$ and $\left.\mathrm{C}_{\mathrm{a}}\right)$.

\section{Physical-chemical parameters}

For each SVOC, measured or estimated values of $\log \left(\mathrm{K}_{\mathrm{ow}}\right)$ and Henry's law constant $(\mathrm{H})$ at $25^{\circ} \mathrm{C}$ were retrieved from: online databases - Hazardous Substances Data Bank (HSBD) and ChemIDplus (http://toxnet.nlm.nih.gov/), Chemspider (http://www.chemspider.com/), and Chemicalize (http://www.chemicalize.org/); toxicological and environmental data sheets from the French National Competence Centre for Industrial Safety and Environmental Protection (INERIS) (http://www.ineris.fr/substances/fr/page/21); online calculators - Chemexper (https://www.chemexper.com/) and ACD/Labs (http://www.acdlabs.com/); EPI Suite software (US EPA, v4.1) and the Handbook of Physical-Chemical Properties and Environment Fate for Organic Chemicals (Mackay et al., 2010a, 2010b, 2010c, 2010d). Only values at $25^{\circ} \mathrm{C}$ (reference temperature) were selected, in order to be consistent and to estimate $\mathrm{DI}_{\text {dermal-gas }}$ at a constant temperature. For each SVOC, where at least 15 values for their $\log \left(\mathrm{K}_{\mathrm{ow}}\right)$ and $\mathrm{H}$ were retrieved from the sources mentioned above, distributions were fitted - and otherwise we used triangular distributions (between minimum, average and maximum values). Corresponding distributions are displayed in Table 1.

\section{Contamination data}

In situation $A\left(C_{g}\right.$ measured): SVOC gas phase concentration values $\left(C_{g}\right)$ were retrieved from Blanchard et al. (2014). When $100 \%$ (i.e. in 30 out of 30 dwellings) of the data were > the limit of quantification (LOQ), log-normal distributions were fitted. When $100 \%$ of the values 
were $<$ LOQ, uniform distributions between 0 and LOQ were used. Lastly when single values were > LOQ, custom distributions were constructed, related to their probabilities of occurrence, with continuous range between 0 and LOQ and discrete ranges for the values > LOQ. In situation B $\left(C_{g}\right.$ measured from $\left.C_{a}\right)$ : SVOC indoor air concentration values $\left(C_{a}\right)$ were retrieved from the literature (Fromme et al., 2004; Fromme et al., 2009 and Rudel et al., 2010). Log-normal distributions were fitted where possible; otherwise custom distributions were constructed, related to their probabilities of occurrence, with continuous ranges from 0 to LOQ and from LOQ to maximum value, or triangular distributions between minimum, average and maximum values. Corresponding distributions are displayed in Table 1.

\section{Human parameters}

We considered a 4-year-old male child to be representative of the sensitive population in terms of the identified toxicological effects and exposure behavior. As an example we searched literature for body weight (W), surface area (A), and time spent in dwellings (t) for a child living in France. Log-normal distributions were used for weight and body surface area. Normal distribution was used for the space-time-budget. Corresponding distributions are displayed in Table 1.

\section{Exposure media properties}

The assessment of gas phase SVOC dermal transfer requires the use of exposure media properties such as $\gamma_{d},[T S P], f_{\text {om-part }}$ and $\rho_{\text {part }}$. Triangular distribution was used for $\gamma_{d}$, using the minimum and maximum values found in the literature and the generally-assumed $6 \mathrm{~m} / \mathrm{h}$ as the most likely value to occur. Log-normal distribution was used for [TSP] and $\mathrm{f}_{\text {om-part }}$. Normal distribution was used for $\rho_{\text {part. }}$ Corresponding distributions are displayed in Table 1.

3. Simulation 
225 Dermal intake sensitivity analysis (Eq. 1) was performed using Crystal Ball@ software 226 (Oracle $^{\odot}$, version 11.1.1.3.00). For each SVOC and for each of the two situations regarding $227 \mathrm{C}_{\mathrm{g}}\left(\mathrm{A}: \mathrm{C}_{\mathrm{g}}\right.$ measured, B: $\mathrm{C}_{\mathrm{g}}$ modeled), Latin Hypercube one-dimensional simulations were 228 carried out with $10^{5}$ runs. 
Table 1: Parameter distributions used in the dermal intake sensitivity analysis from gas phase for 8 SVOCs.

\begin{tabular}{|c|c|c|c|c|c|c|c|c|c|}
\hline $\begin{array}{c}\text { Paramete } \\
\mathbf{r}\end{array}$ & DMP & $\begin{array}{c}\text { Phenanthren } \\
\text { e }\end{array}$ & НHCB & Permethrin & Diazinon & PCB105 & BPA & BDE154 & Sources \\
\hline$\frac{\log }{\left(\mathrm{K}_{\mathrm{ow}}\right)^{*}}$ & $\begin{array}{c}\text { Log-normal } \\
\min =1.35 \\
\mu=1.65 \\
\sigma=0.14\end{array}$ & $\begin{array}{c}\text { Logistic } \\
\mu=4.50 \\
\text { scale }=0.09\end{array}$ & $\begin{array}{c}\text { Triangular } \\
\min =3.42 \\
\mu=5.23 \\
\max =6.26\end{array}$ & $\begin{array}{c}\text { Minimum } \\
\text { extreme } \\
\text { likeliest }=6.51 \\
\text { scale }=0.73\end{array}$ & $\begin{array}{c}\text { Minimum extreme } \\
\text { likeliest }=3.74 \\
\text { scale }=0.37\end{array}$ & $\begin{array}{c}\text { Minimum extreme } \\
\text { likeliest }=6.72 \\
\text { scale }=0.35\end{array}$ & $\begin{array}{c}\text { Triangular } \\
\min =3.32 \\
\mu=3.48 \\
\max =4.04\end{array}$ & $\begin{array}{c}\text { Triangular } \\
\min =6.86 \\
\mu=7.89 \\
\max =8.83\end{array}$ & \multirow{2}{*}{$\begin{array}{c}\text { Internet } \\
\text { databases***, } \\
\text { Chemexper, } \\
\text { ACD/Labs } \\
\text { calculators, EPI } \\
\text { Suite software (US } \\
\text { EPA, v4.1), Mackay } \\
\text { et al., 2010a, 2010b, } \\
\text { 2010c, 2010d. }\end{array}$} \\
\hline $\begin{array}{c}\mathrm{H}^{*} \\
\left(\mathrm{~Pa} \cdot \mathrm{m}^{3} / \mathrm{m}\right. \\
\mathrm{ol})\end{array}$ & $\begin{array}{c}\text { Triangular } \\
\min =6.20 \mathrm{E}-3 \\
\mu=3.60 \mathrm{E}-2 \\
\max =1.11 \mathrm{E}-1\end{array}$ & $\begin{array}{c}\text { Triangular } \\
\min =2.38 \\
\mu=3.74 \\
\max =5.55\end{array}$ & $\begin{array}{c}\text { Uniform } \\
\min =7.66 \mathrm{E}-2 \\
\max =1.34 \mathrm{E}+1\end{array}$ & $\begin{array}{c}\text { Triangular } \\
\min =2.33 \mathrm{E}-6 \\
\mu=5.34 \mathrm{E}-2 \\
\max =1.89 \mathrm{E}-1\end{array}$ & $\begin{array}{c}\text { Triangular } \\
\min =7.00 \mathrm{E}-3 \\
\mu=4.25 \mathrm{E}-2 \\
\max =1.44 \mathrm{E}-1\end{array}$ & $\begin{array}{c}\begin{array}{c}\text { Triangular } \\
\text { min }=2.43\end{array} \\
\mu=2.24 \mathrm{E}+1 \\
\max =8.36 \mathrm{E}+1\end{array}$ & $\begin{array}{c}\text { Triangular } \\
\min =9.28 \mathrm{E}-7 \\
\mu=2.49 \mathrm{E}-6 \\
\max =4.05 \mathrm{E}-6\end{array}$ & $\begin{array}{c}\text { Triangular } \\
\min =4.77 \mathrm{E}-2 \\
\mu=1.46 \mathrm{E}-1 \\
\max =2.40 \mathrm{E}-1\end{array}$ & \\
\hline$\underset{\left(\mathrm{ng} / \mathrm{m}^{3}\right)}{\mathrm{C}_{\mathrm{g}}}$ & $\begin{array}{c}\text { Log-normal } \\
\text { min }=0 \\
\mu_{\mathrm{g}}=8.57 \\
\sigma_{\mathrm{g}}=2.23\end{array}$ & $\begin{array}{c}\text { Log-normal } \\
\min =4.16 \\
\mu_{\mathrm{g}}=3.88 \\
\sigma_{\mathrm{g}}=2.98\end{array}$ & $\begin{array}{c}\text { Log-normal } \\
\min =0 \\
\mu_{\mathrm{g}}=6.67 \mathrm{E}+1 \\
\sigma_{\mathrm{g}}=2.57\end{array}$ & $\begin{array}{c}\text { Uniform } \\
{[0-0.6(\mathrm{LOQ})]}\end{array}$ & $\begin{array}{c}\text { Discrete }(\mathrm{p}=0.03) \\
2.45 \\
\text { Uniform }(\mathrm{p}=0.97) \\
{[0-0.6(\mathrm{LOQ})]}\end{array}$ & $\begin{array}{c}\text { Discrete }(\mathrm{p}=0.03) \\
0.4 \\
\text { Uniform }(\mathrm{p}=0.97) \\
{[0-0.25(\mathrm{LOQ})]}\end{array}$ & $\begin{array}{c}\text { Uniform } \\
{[0-0.6(\mathrm{LOQ})]}\end{array}$ & $\begin{array}{c}\text { Uniform } \\
{[0-0.6(\mathrm{LOQ})]}\end{array}$ & $\begin{array}{l}\text { Blanchard et al., } \\
2014 .\end{array}$ \\
\hline $\begin{array}{c}\mathrm{C}_{\mathrm{a}} \\
\left(\mathrm{ng} / \mathrm{m}^{3}\right)\end{array}$ & $\begin{array}{c}\text { Log-normal } \\
\mu=1.18 \mathrm{E}+3 \\
\text { p50 }=4.36 \mathrm{E}+2 \\
\text { p95 }=4.65 \mathrm{E}+3\end{array}$ & $\begin{array}{c}\begin{array}{c}\text { Log-normal } \\
\mu=6.1\end{array} \\
\text { p50=1.10E+1 } \\
\text { p95=2.90E+1 }\end{array}$ & $\begin{array}{c}\text { Log-normal } \\
\mu=1.19 \mathrm{E}+2 \\
\text { p50=1.01E+2 } \\
\text { p95=2.45E+2 }\end{array}$ & $\begin{array}{c}\text { Uniform }(\mathrm{p}=0.92) \\
{[0-0.3(\mathrm{LOQ})]} \\
\text { Uniform }(\mathrm{p}=0.08) \\
{[0.3(\mathrm{LOQ})-2]}\end{array}$ & $\begin{array}{c}\text { Uniform }(\mathrm{p}=0.98) \\
{[0-0.3(\mathrm{LOQ})]} \\
\text { Uniform }(\mathrm{p}=0.02) \\
{[0.3(\mathrm{LOQ})-} \\
3.1 \mathrm{E}+1]\end{array}$ & $\begin{array}{c}\text { Uniform }(\mathrm{p}=0.88) \\
{[0-0.3(\mathrm{LOQ})]} \\
\text { Uniform }(\mathrm{p}=0.12) \\
{[0.3(\mathrm{LOQ})-1.2]}\end{array}$ & $\begin{array}{c}\text { Uniform }(\mathrm{p}=0.84) \\
{[0-0.8(\mathrm{LOQ})]} \\
\text { Uniform }(\mathrm{p}=0.16) \\
{[0.8(\mathrm{LOQ})-} \\
2.2 \mathrm{E}+1]\end{array}$ & $\begin{array}{c}\begin{array}{c}\text { Triangular } \\
\text { min }=0\end{array} \\
\mu=6.20 \mathrm{E}-4 \\
\max =1.09 \mathrm{E}-2\end{array}$ & $\begin{array}{l}\text { Rudel et al., 2010 } \\
\text { (phen, per, diaz, } \\
\text { PCB105, BPA), } \\
\text { Fromme et al., 2004 } \\
\text { (DMP, HHCB), } \\
\text { Fromme et al., 2009 } \\
\text { (BDE154). }\end{array}$ \\
\hline $\begin{array}{c}\mathrm{Y}_{\mathrm{d}} \\
(\mathrm{m} / \mathrm{h})\end{array}$ & \multicolumn{8}{|c|}{$\begin{array}{c}\text { Triangular } \\
\min =5, \text { likeliest }=6, \max =10\end{array}$} & $\begin{array}{l}\text { Tamas et al., 2006; } \\
\text { Pandrangi and } \\
\text { Morrison, 2008; } \\
\text { Weschler and } \\
\text { Nazaroff, 2008. }\end{array}$ \\
\hline $\begin{array}{c}{[\mathrm{TSP}]} \\
\left(\mu \mathrm{g} / \mathrm{m}^{3}\right) \\
\end{array}$ & \multicolumn{8}{|c|}{ Log-normal, $\mu_{\mathrm{g}}=37.34, \sigma_{\mathrm{g}}=2.17, \mathrm{p} 95=182$} & $\begin{array}{l}\text { Ramalho et al., } \\
2012 .\end{array}$ \\
\hline $\mathrm{f}_{\text {om-part }}$ & \multicolumn{8}{|c|}{ Normal, $\mu=0.35, \sigma=0.2$} & $\begin{array}{l}\text { Salthammer and } \\
\text { Schripp, } 2015 .\end{array}$ \\
\hline $\begin{array}{c}\rho_{\text {part }} \\
\left(\mathrm{g} / \mathrm{m}^{3}\right)\end{array}$ & \multicolumn{8}{|c|}{ Normal, $\mu=1.6 \mathrm{E}+6, \sigma=0.5 \mathrm{E}+6$} & Pitz et al., 2003. \\
\hline $\begin{array}{l}\mathrm{W}^{* *} \\
(\mathrm{~kg})\end{array}$ & \multicolumn{8}{|c|}{ Log-normal, $\mu \ln x=2.68, \sigma \ln x=0.17, p 95=22.0$} & Tanguy et al., 2007. \\
\hline $\begin{array}{l}\mathrm{A}^{* * *} \\
\left(\mathrm{~m}^{2}\right)\end{array}$ & \multicolumn{8}{|c|}{ Log-normal, $\mu=-0.28, \sigma=0.12, p 95=0.94$} & $\begin{array}{l}\text { Sabaterie et al., } \\
2013 \text {. }\end{array}$ \\
\hline $\begin{array}{c}\mathrm{T} \\
(\mathrm{h} / \mathrm{d})\end{array}$ & \multicolumn{8}{|c|}{ Normal, $\mu=17.17, \sigma=0.63$} & $\begin{array}{l}\text { Zeghnoun and Dor, } \\
2010 .\end{array}$ \\
\hline
\end{tabular}


A: body surface area; BPA: bisphenol A; $\mathrm{C}_{\mathrm{a}}$ : SVOC total concentration in indoor air; $\mathrm{C}_{\mathrm{g}}$ : SVOC concentration in the gas phase; diaz: diazinon; DMP: dimethyl phthalate; $\mathrm{f}_{\text {om-part }}$ : volume fraction of organic matter associated with airborne particles; $\gamma_{d}$ : coefficient describing the external transport of a gas phase SVOC from the bulk indoor air to the boundary layer adjacent to the skin; $\mathrm{H}$ : Henry's law constant; HHCB: galaxolide; $\mathrm{K}_{\mathrm{ow}}$ : octanol/water partition coe $_{\mathrm{f}}$ ficient; $\mu$ : arithmetic mean; $\mu_{\mathrm{g}}$ : geometric mean; per: permethrin; phe: phenanthrene; $\rho_{\text {part }}$ : density of airborne particles; $\sigma$ : standard deviation; $\sigma_{\mathrm{g}}$ : geometric standard deviation; t: daily exposure duration; [TSP]: total suspended particle concentration; W: body weight. Distribution parameters may be different for a same distribution law because of diversity of reporting data in the literature.

$236 *$ : Measured or estimated at $25^{\circ} \mathrm{C}$.

237 **: Spearman's rank correlation between mass and body surface area is 0.99 for a 4-year-old male child (Sabaterie et al., 2013).

***: Hazardous Substances Data Bank (HSBD), ChemIDplus, Chemspider, Chemicalize and the French toxicological and environmental data sheets from INERIS. 
Daily dermal intake variations are presented in Table 2.

Table 2: Variations in daily dermal intake $\left(\mathrm{DI}_{\text {dermal-gas }}\right)$, expressed as the relative interdecile range, for each SVOC and for each of the two situations regarding gas phase concentration (A: $\mathrm{C}_{\mathrm{g}}$ measured, $\mathrm{B}: \mathrm{C}_{\mathrm{g}}$ modeled).

\begin{tabular}{|c|c|c|}
\hline Situation & SVOC & $\begin{array}{l}\text { Relative interdecile range } \\
\qquad=\frac{d 90-d 10}{d 50}\end{array}$ \\
\hline \multirow{8}{*}{ A } & Dimethyl phthalate (DMP) & 3.1 \\
\hline & Phenanthrene & 1.9 \\
\hline & Galaxolide (HHCB) & 6.3 \\
\hline & Permethrin & 2.2 \\
\hline & Diazinon & 3.1 \\
\hline & PCB 105 & 2.8 \\
\hline & Bisphenol A (BPA) & 1.2 \\
\hline & BDE 154 & 1.6 \\
\hline \multirow{8}{*}{ B } & Dimethyl phthalate (DMP) & 6.2 \\
\hline & Phenanthrene & 1.4 \\
\hline & Galaxolide (HHCB) & 2.8 \\
\hline & Permethrin & 3.6 \\
\hline & Diazinon & 3.1 \\
\hline & PCB 105 & 3.7 \\
\hline & Bisphenol A (BPA) & 17.8 \\
\hline & BDE 154 & 7.3 \\
\hline
\end{tabular}

247 The relative interdecile range of $\mathrm{DI}_{\text {dermal-gas, }}$, when $\mathrm{C}_{\mathrm{g}}$ value is measured (situation $\mathrm{A}$ ), ranged 248 from 1.2 for BPA to 6.3 for galaxolide (HHCB). When $\mathrm{C}_{\mathrm{g}}$ is estimated from $\mathrm{C}_{\mathrm{a}}$ (situation $\mathrm{B}$ ), $249 \mathrm{DI}_{\text {dermal-gas }}$ variation was highest for BPA having a relative interdecile range of 17.8 and 250 lowest for phenanthrene, at 1.4. The following sensitivity analysis results allow us to interpret $251 \mathrm{DI}_{\text {dermal-gas }}$ variation, particularly for compounds having high relative interdecile ranges. 


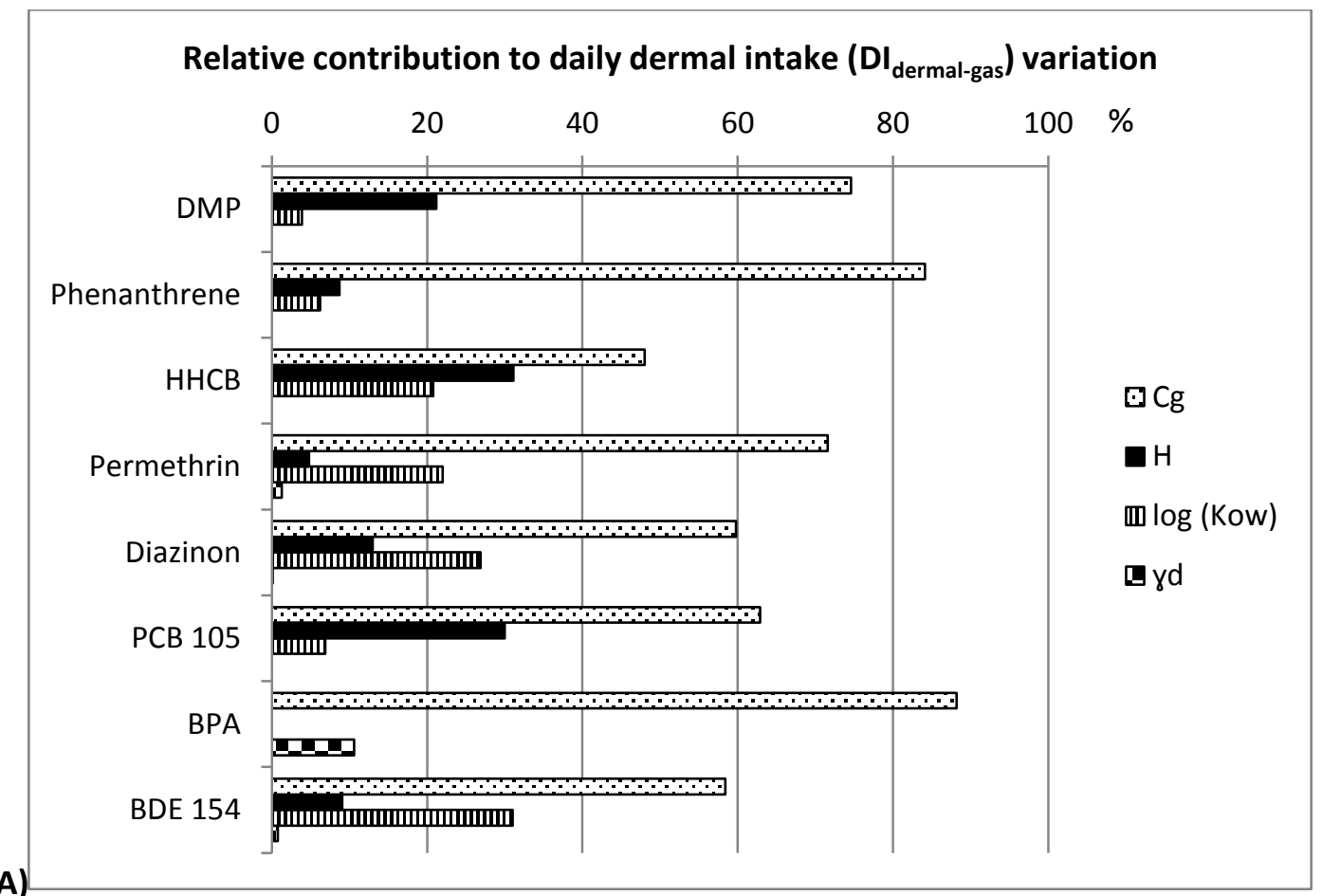

Relative contribution to daily dermal intake ( $\mathrm{DI}$ dermal-gas $)$ variation

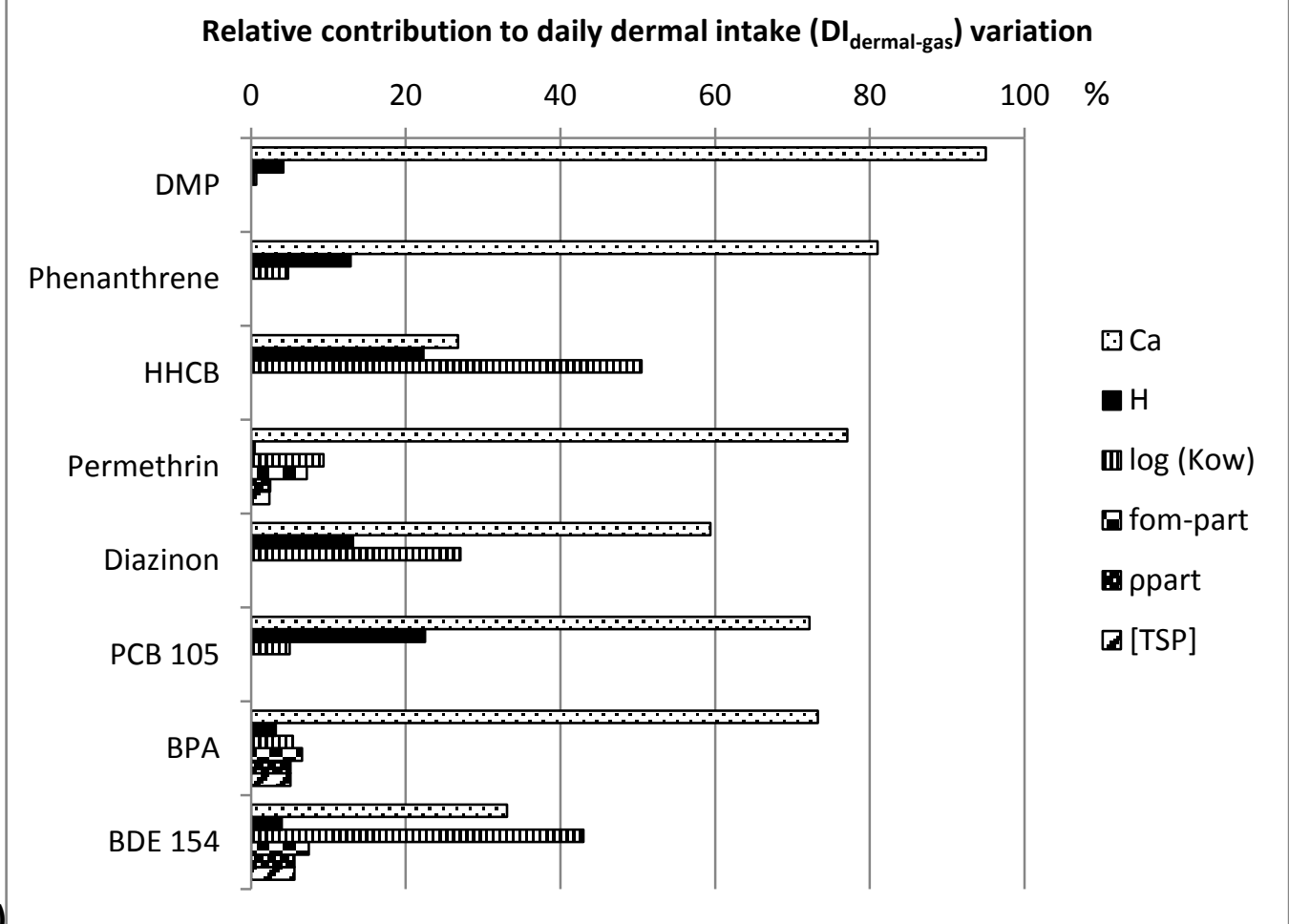

257 Figure 1: Relative contribution (\%) to total variation of gaseous SVOC daily dermal intakes

$258(\mu \mathrm{g} / \mathrm{kg}-\mathrm{bw} / \mathrm{d})$ according to key parameters: $\mathrm{C}_{\mathrm{g}}, \mathrm{C}_{\mathrm{a}}, \log \left(\mathrm{K}_{\mathrm{ow}}\right), \mathrm{H}, \mathrm{\gamma}_{\mathrm{d}}, \mathrm{f}_{\text {om-part, }}, \rho_{\text {part }}$, and [TSP] for 259 both situations: A) $C_{g}$ is measured and B) $C_{g}$ is estimated from $C_{a}$. 
261 Results of the sensitivity analysis are presented in Figure 1 as tornado charts, showing relative 262 contributions to total variation of gas phase SVOC daily dermal intakes $(\mu \mathrm{g} / \mathrm{kg}-\mathrm{bw} / \mathrm{d})$ 263 according to key parameters. Parameters having a relative contribution that is always lower 264 than $5 \%$ are not shown in Figure 1, that is, each of the human parameters: $\mathrm{W}, \mathrm{A}$ and $\mathrm{t}$ (situation $\mathrm{A}$ and $\mathrm{B})$ and $\mathrm{\gamma}_{\mathrm{d}}$ (only for situation B).

The sensitivity analysis of $\mathrm{DI}_{\text {dermal-gas }}$ calculation, when $\mathrm{C}_{\mathrm{g}}$ is measured (situation $\mathrm{A}$ ), reveals that for the studied compounds the most influential parameters are: $\mathrm{C}_{\mathrm{g}}, \mathrm{H}$ and $\log \left(\mathrm{K}_{\mathrm{ow}}\right)$. $\mathrm{DI}_{\text {dermal-gas }}$ estimation is mainly driven by variability in $\mathrm{C}_{\mathrm{g}}$.

When $\mathrm{C}_{\mathrm{g}}$ is estimated from $\mathrm{C}_{\mathrm{a}}$ (situation $\mathrm{B}$ ), $\mathrm{DI}_{\text {dermal-gas }}$ variation is dominated by variability in $\mathrm{C}_{\mathrm{a}}$, with the exception of HHCB and BDE 154 for which it is mainly driven by uncertainty in $\log \left(\mathrm{K}_{\mathrm{ow}}\right)$. For permethrin and BDE 154, uncertainties in $\mathrm{f}_{\text {om-part, }} \rho_{\text {part }}$ and $[\mathrm{TSP}]$ are also 272 significant, though less influential in $\mathrm{DI}_{\text {dermal-gas }}$ calculation.

For a given age group in both situations, the following parameters make a marginal or null contribution to $\mathrm{DI}_{\mathrm{dermal}-\mathrm{gas}}$ variation for all of the studied SVOCs: $\mathrm{t}, \mathrm{W}, \mathrm{A}$, and $\mathrm{\gamma d}_{\mathrm{d}}$ - with the exception of BPA in situation A, for which $\gamma_{d}$ makes a significant contribution. Indoor air SVOCs concentrations can be variable and/or uncertain. Variabilities in indoor air concentrations $\left(\mathrm{C}_{\mathrm{g}}\right.$ and $\left.\mathrm{C}_{\mathrm{a}}\right)$ are high due to several conditions, such as differences in occupant 279 habits, variety of sources, and dwelling characteristics. For example, Clausen et al. (2012) 280 found that indoor temperature has a significant influence on DEHP air concentrations: this 281 increases by a factor of about 10 with an increase of $12^{\circ} \mathrm{C}$ in indoor temperature. Furthermore, these concentrations may vary considerably from one country to another 
depending, for example, on national regulations regarding the use of specific SVOCs (Weschler and Nazaroff, 2008). In this sensitivity analysis, $C_{g}$ and $C_{a}$ were retrieved from studies (Fromme et al., 2004; Fromme et al., 2009; Rudel et al., 2010 and Blanchard et al., 2014) having measured these concentrations at various indoor temperatures and in different countries. But $\mathrm{C}_{\mathrm{g}}$ and $\mathrm{C}_{\mathrm{a}}$ are also uncertain, especially when all or most values are below the LOQ. When $\mathrm{C}_{\mathrm{g}}$ and $\mathrm{C}_{\mathrm{a}}$ values were below the LOQ (permethrin, diazinon, PCB 105, BPA and BDE 154), the applied distribution shape (custom, triangular and uniform) also brings uncertainty to these unknown values. In order to assess the impact of the distribution on $\mathrm{C}_{\mathrm{g}}$ and $\mathrm{C}_{\mathrm{a}}$ uncertainty, triangular distributions (between $0, \mathrm{LOQ} / 2$ and LOQ) were also tested in place of uniform distributions (data not shown). The same results were found, providing evidence that distribution shape does not influence the relative contribution of $C_{g}$ and $C_{a}$ uncertainty in $\mathrm{DI}_{\mathrm{dermal} \text {-gas }}$ result variation.

Moreover, some LOQs used as maxima in uniform distribution regarding $\mathrm{C}_{\mathrm{g}}$ (permethrin, BPA and BDE 154) are open to discussion because they are high in comparison with other studies in which fewer compounds were measured at the same time. This uncertainty can lead to discrepancy between the two situations regarding the distribution we used, especially for BDE 154 concentrations in indoor air (see Table 1 ) where $C_{g}$ maximum value $(0.6=\mathrm{LOQ}$ ) is larger than $\mathrm{C}_{\mathrm{a}}$ maximum (0.01). This unrealistic situation is the only one in our study - but it is important to bear in mind that the objective here is a sensitivity analysis linked to information availability, rather than an exposure assessment.

4. Uncertainty in physical-chemical parameter values

Physical-chemical parameters can either be measured experimentally or calculated using other chemical properties. Depending on which of these methods is used, it follows that values vary by one order of magnitude or more (Finizio et al., 1997) - and these uncertainties will be 
propagated in the calculation of $\mathrm{k}_{\mathrm{p}-\mathrm{g}}, \mathrm{C}_{\mathrm{g}}$ and $\mathrm{DI}_{\text {dermal-gas. }}$ On this topic, Weschler and Nazaroff (2008) warned that $\mathrm{H}, \mathrm{K}_{\mathrm{ow}}$ and $\mathrm{K}_{\mathrm{oa}}$ values, calculated using the SPARC Online Calculator v4.0 (Hilal et al., 2003, 2004), sometimes vary substantially from experimentally derived values. For the same parameters, Schossler et al. (2011) demonstrated that values vary by one order of magnitude or more between the results obtained using software tools such as EPI Suite (US EPA, 2013) or the SPARC Online Calculator v4.6. In this study, $\log \left(\mathrm{K}_{\mathrm{ow}}\right)$ and $\mathrm{H}$ values were collected from several databases, online calculators and literature sources at $25^{\circ} \mathrm{C}$, and for each SVOC (see Table 1). The wide intervals obtained for certain compounds such as $\mathrm{H}$ for $\mathrm{HHCB}$ - corroborate the relatively high level of uncertainty for these parameters.

When assessing gas/particle SVOC distribution (see Equation 8 in the supplementary material for the detailed calculation), Salthammer and Schripp (2015) assumed normal distributions for $\mathrm{H}$ and $\log \left(\mathrm{K}_{\mathrm{ow}}\right)$. Due to the lack of data (as discussed above) the authors calculated mean and standard deviation, in order to build normal distribution using just two values for certain compounds. In our study, where at least 15 values for these parameters were retrieved from literature, log-normal distributions were fitted - otherwise we used triangular, minimum extreme or logistic distributions (see Table 1). However, in order to assess the impact of distribution, other distributions, such as uniform, were also tested and the same parameters were found to be most sensitive regarding $\mathrm{DI}_{\text {dermal-gas }}$ variability, providing evidence that choice of distribution shape does not influence the relative contribution made by $\mathrm{H}$ and $\log$ $\left(\mathrm{K}_{\mathrm{ow}}\right)$ in $\mathrm{DI}_{\text {dermal-gas }}$ result variation. variability, depending on the range of $\mathrm{H}$ and $\log \left(\mathrm{K}_{\mathrm{ow}}\right)$ values. For example, $\mathrm{H}$ values for HHCB range from [7.66E-2 to 13.4], which logically leads to this parameter having a greater influence on $\mathrm{DI}_{\text {dermal-gas }}$ variability (see Figure 1). These results are consistent with previous 
studies: Weschler and Nazaroff (2014) assessed $\mathrm{k}_{\mathrm{p}-\mathrm{g}}$ sensitivity (see Equation 2) to the same key parameters and also found that the permeability coefficient was more sensitive to $\mathrm{H}$. In the same way, Salthammer and Schripp (2015) assessed the sensitivity of $\mathrm{K}_{\mathrm{p}}$ (see Equations 8 and 9 in the supplementary material for the detailed calculation) and found that the error margin in $\mathrm{K}_{\mathrm{p}}$ calculation was dominated by $\mathrm{H}$ uncertainty. Because $\log \left(\mathrm{K}_{\mathrm{ow}}\right)$ and $\mathrm{H}$ are two of the most influential parameters on $\mathrm{DI}_{\text {dermal-gas }}$ variation for every SVOC and in both situations, reducing their uncertainties could significantly reduce variation on $\mathrm{DI}_{\text {dermal-gas }}$ and uncertainty in exposure analysis.

\section{Uncertainty in exposure media properties}

In earlier studies, default values were used for $\mathrm{f}_{\text {om-part }}, \rho_{\text {part }}$, [TSP] and $\gamma_{d}$. Regarding the volume fraction of organic matter associated with airborne particles, $\mathrm{f}_{\text {om-part }}$, we assumed the same normal distribution parameters as Salthammer and Schripp (2015). Regarding particle density, $\rho_{\text {part }}$, several values are found in the literature and $1.10^{6} \mathrm{~g} / \mathrm{m}^{3}$ is often assumed, as a default value (Turpin and Lim, 2001). In order to assess $\mathrm{DI}_{\text {dermal-gas }}$ sensitivity to this parameter, normal distribution was used rather than a single value (Pitz et al., 2003). Regarding total suspended particle concentration, [TSP], a default value of $20 \mu \mathrm{g} / \mathrm{m}^{3}$ was assumed by Weschler and Nazaroff (2008). More recently, Salthammer and Schripp (2015) found that [TSP] strongly influenced gas/particle partitioning, and we decided to build a lognormal distribution for this parameter using data on indoor $\mathrm{PM}_{10}$ concentrations (Ramalho et al., 2012). These data are weekly-averaged, and cover different climate zones and seasons. Regarding $\gamma_{d}$, a value of $6 \mathrm{~m} / \mathrm{h}$ is assumed for the coefficient describing the external transport of a gas phase SVOC from bulk indoor air to the boundary layer adjacent to the skin (Weschler and Nazaroff, 2012). The authors have previously estimated this parameter to range between 5 and $10 \mathrm{~m} / \mathrm{h}$ (Weschler and Nazaroff, 2008). In this study, triangular distribution was built between these three values. This parameter variation's influence on 
$\mathrm{DI}_{\text {dermal-gas }}$ variation was insignificant, with the exception of BPA in situation A (see Figure 1,

358 A). Nevertheless, Weschler and Nazaroff (2008) also proposed an estimate of $3 \mathrm{~m} / \mathrm{h}$ for the mass-transfer coefficient. In order to provide a comprehensive sensitivity analysis we

360 assessed different distribution shapes: triangular with a minimum of 3, a likeliest value of 6 and a maximum of 10 and uniform between 3 and 10. The results (not shown) were identical and $\gamma_{d}$ did not become an influential parameter.

While exposure media properties such as $\mathrm{f}_{\text {om-part, }} \rho_{\text {part, }}$ [TSP] and $\gamma_{d}$ have a slight influence (less than 10\%, see Figure 1) for some compounds (permethrin, BPA and BDE 154), they make a marginal or null contribution (less than $5 \%$ ) to the variance of dermal intake for a given age group, for the other SVOCs and in both situations.

6. Variability in human parameters

Human parameters such as body weight $(\mathrm{W})$, body surface area (A) and daily exposure (t) make a marginal or null contribution (less than 5\%) to the variance of dermal intake for a given age group, for each SVOC and in each situation. However, one has to bear in mind that we ran the model for a given age group and that these parameters would have a larger impact when applied on a more diverse population. Regarding the role of clothing in dermal exposure, Piotrovski (1971) assessed the exposed body surface area (A) and found little difference in dermal absorption between clothed and naked people exposed to phenol vapor. More recently Morrison et al. (2016) assessed the influence of clothing on the dermal uptake of two phthalates (DEP and DnBP). The authors found that clean clothes were protective against air pollutants; whereas worn clothes, because they have adsorbed air pollutants, increased dermal intake. Because only clean clothes could be considered protective, we decided to not take into account the role of clothing in this sensitivity analysis, and to assume total body surface area exposed to indoor air when calculating $\mathrm{DI}_{\text {dermal-gas. }}$. However, the fact 
that we found A to make a marginal or null contribution (less than $5 \%$ ) to the variance of dermal intake, does not mean that clothing should not, when possible, be taken into account in assessing dermal exposure. In this case the proportion of exposed body surface area has to be taken into account.

In addition to the important role of clothing, other parameters not included in this model are suspected of influencing or playing a role in dermal exposure were not taken into account in this sensitivity analysis: skin temperature, metabolic processes on (e.g. ionization) or in the skin, the effects of bathing on SVOC levels in skin-surface lipids, etc.

Furthermore, it is important to bear in mind that we did not assess model uncertainty - only parametric uncertainty when using this model. A first source of uncertainty is model boundaries. Indeed our model relies partly on equation of Mitragotri (2002) that may lead to greater uncertainty when MW is higher than 400, which is the case for BDE 154 . In addition, more sophisticated, and recent, models exist taking into account the dynamics of aerosols and/or the clothing effect. Regarding the dynamics of aerosols, Shi and Zao (2015) showed that, in their model, air exchange rate and surfaces cleaning frequency were influential parameters, while density of settled dust and its organic fraction were important media properties. Also, the transient model proposed by Gong et al. (2014), addresses the rapidly changing conditions and concentrations and considers a convective mass transfer resistance in the boundary air layer adjacent to the skin, and leads to lower estimates of dermal uptake. Morrison et al. (2016) improved this model taking clothing effect modeling, and showed that bathing frequency and change of clothes frequency were influential. Also, the introduction of a skin surface lipid film in the models and its interactions with clothing may affect the results, so do the corresponding additional parameters, such as for instance the thickness of this lipidic film. 


\section{CONCLUSION}

When assessing dermal absorption of gas phase SVOCs, variation of dermal intake estimation is driven firstly by variability and uncertainty in indoor air concentration $\left(\mathrm{C}_{\mathrm{g}}\right.$ or $\left.\mathrm{C}_{\mathrm{a}}\right)$, and secondly by uncertainty in SVOC physical-chemical parameters: $\log \left(\mathrm{K}_{\mathrm{ow}}\right)$ and $\mathrm{H}$. While exposure media properties such as volume fraction of organic matter in the particle phase $\left(\mathrm{f}_{\text {om- }}\right.$ part), particle density $\left(\rho_{\text {part }}\right)$, concentration ([TSP]) and transport coefficient $\left(\mathrm{\gamma}_{\mathrm{d}}\right)$ do have a slight influence (less than 10\%) for some compounds, human parameters such as body weight (W), body surface area (A) and daily exposure (t) make a marginal or null contribution (less than $5 \%$ ) to the variance of dermal intake for a given age group.

Considering that $\mathrm{DI}_{\text {dermal-gas }}$ variation can be high for some compounds, exposure assessors aiming to assess $S V O C D_{d e r m a l-g a s}$ using the $k_{p-g}$, or to estimate $C_{g}$ from $C_{a}$, must pay particular attention to the determination, estimation, and selection of the following SVOCspecific parameters: concentration in gas phase $\left(\mathrm{C}_{\mathrm{g}}\right)$ or indoor air $\left(\mathrm{C}_{\mathrm{a}}\right), \mathrm{K}_{\mathrm{ow}}$ and $\mathrm{H}$.

It is however important to remain aware, when analyzing these results, that exposure to an SVOC is strongly dependent on its partition between gas phase and particulate phase. When an SVOC is more abundant in the gas phase, dermal absorption will be greater than dust ingestion, and conversely, when a SVOC is more present in the particulate phase, dust ingestion is likely to be greater than dermal absorption (Weschler and Nazaroff, 2012). Therefore, less volatile SVOCs $\left(\mathrm{P}_{\mathrm{s}}<10^{-6} \mathrm{~Pa}\right)$, which are more present in the particulate phase and have a low predicted dermal absorption, do not require the same caution in estimation of dermal intake in order to assess their total exposure to indoor SVOC.

In general, inclusion of an uncertainty analysis in exposure assessment appears to be essential. In view of these sensitivity analysis results, reducing $\log \left(\mathrm{K}_{\mathrm{ow}}\right)$ and $\mathrm{H}$ uncertainties could significantly reduce uncertainties in $\mathrm{DI}_{\text {dermal-gas }}$ assessment. 
This research did not receive any specific grant from funding agencies in the public, commercial, or not-for-profit sectors.

\section{REFERENCES}

433

434

435

436

437

438

439

440

441

442

443

444

445

446

447

448

449

450

Armstrong, B. Hutchinson, E. Unwin, J. and Fletcher, T. (2004) Lung cancer risk after exposure to polycyclic aromatic hydrocarbons: A review and meta-analysis, Environ. Health Persp., 112, 970-978.

Baldi, I. Filleul, L. Mohammed-Brahim, B. Fabrigoule, C. Dartigues, J.F. Schwall, S. Drevet, J.P. Salamon, R. and Brochard, P. (2001) Neuropsychologic effects of long-term exposure to pesticides: Results from the French Phytoner study, Environ. Health Persp., 109, 839-844.

Beko, G. Weschler, C.J. Langer, S. Callesen, M. Toftum, J. and Clausen, G. (2013) Children's Phthalate Intakes and Resultant Cumulative Exposures Estimated from Urine Compared with Estimates from Dust Ingestion, Inhalation and Dermal Absorption in Their Homes and Daycare Centers, PLoS One 8(4), e62442.

Blanchard, O. Glorennec, P. Mercier, F. Bonvallot, N. Chevrier, C. Ramalho, O. Mandin, C. and Le Bot, B. (2014) Semivolatile Organic Compounds in Indoor Air and Settled Dust in 30 French Dwellings, Environ. Sci. Technol., 48, 3959-3969.

Blanc-Lapierre, A. Bouvier, G. Garrigou, A, Canal-Raffin, M. Raherison, C. Brochard, P. and Baldi, I. (2012) Chronic central nervous system effects of pesticides : state-of-the-art, Rev. Epidemiol. Sante., 60(5), 389-400.

Bonvallot, N. Mandin, C. Mercier, F. Le Bot, B. and Glorennec, P. (2010) Health ranking of ingested semivolatile organic compounds in house dust: an application to France, Indoor Air, 
452

453

454

455

456

457

458

459

460

461

462

463

464

465

466

467

468

469

470

471

472

473

Clausen, P. A. Liu, Z. Kofoed-Sørensen, V. Little, J. and Wolkoff, P. (2012) Influence of temperature on the emission of di-(2-ethylhexyl) phthalate (DEHP) from PVC flooring in the emission cell FLEC, Environ. Sci. Technol,. 46, 2, 909-915.

Elbaz, A. Clavel, J. Rathouz, P.J. Moisan, F. Galanaud, J.P. Delemotte, B. Alperovitch, A. and Tzourio, C. (2009) Professional Exposure to Pesticides and Parkinson Disease, Ann. Neurol., 66, 494-504.

Finizio, A. Mackay, D. Bidleman, T. and Harner, T. (1997) Octanol-air partition coefficient as a predictor of partitioning of semivolatile organic chemicals to aerosols, Atmos. Environ., $31,2289-2296$.

Fromme, H. Koerner, W. Shahin, N. Wanner, A. Albrecht, M. Boehmer, S. Parlar, H. Mayer, R. Liebl, B. and Bolte, G. (2009) Human exposure to polybrominated diphenyl ethers (PBDE), as evidenced by data from a duplicate diet study, indoor air, house dust, and biomonitoring in Germany, Environ. Int., 35, 1125-1135.

Fromme, H. Lahrz, T. Hainsch, A. Oddoy, A. Piloty, M. and Ruden, H. (2005) Elemental carbon and respirable particulate matter in the indoor air of apartments and nursery schools and ambient air in Berlin (Germany), Indoor Air, 15, 335-341.

Fromme, H. Lahrz, T. Piloty, M. Gebhart, H. Oddoy, A. and Ruden, H. (2004) Occurrence of phthalates and musk fragrances in indoor air and dust from apartments and kindergartens in Berlin (Germany), Indoor Air, 14, 188-195.

Glorennec, P. Mercier, F. Blanchard, O. Bonvallot, N. Ramalho, O. Mandin, C. and Le Bot, B. (2011) Cumulative indoor exposures to Semivolatile Organic Compounds (SVOCs) in France: the ECOS project, Indoor Air Conference, Austin, Texas, USA. https://hal.archives- 
Gong, M. Zhang, Y. and Weschler, C.J. (2014) Predicting dermal absorption of gas phase chemicals: transient model development, evaluation, and application, Indoor Air, 24, 292306.

Grandjean, P. Bellinger, D. Bergman, A. Cordier, S. Davey-Smith, G. Eskenazi, B. Gee, D. Gray, K. Hanson, M. Van den Hazel, P. Heindel, J.J. Heinzow, B. Hertz-Picciotto, I. Hu, H. Huang, T.T.K. Jensen, T.K. Landrigan, P.J. McMillen, I.C. Murata, K. Ritz, B. Schoeters, G. Skakkebaek, N.E. Skerfving, S. and Weihe, P. (2008) The faroes statement: Human health effects of developmental exposure to chemicals in our environment, Basic Clin. Pharmacol. Toxicol., 102, 73-75.

IARC (2015a) Polychlorinated biphenyls and polybrominated biphenyls, IARC Monogr. Eval. Carcinog. Risk Chem. Hum., Vol. 107, (available online: http://monographs.iarc.fr/ENG/Monographs/vol107/index.php).

IARC (2015b) Some organophosphate insecticides and herbicides: diazinon, glyphosate, malathion, parathion, and tetrachlorvinphos, IARC Monogr. Eval. Carcinog. Risk Chem. $\begin{array}{llll}\text { Hum., } & \text { Vol. } & \text { (available http:// }\end{array}$ http://monographs.iarc.fr/ENG/Monographs/vol112/index.php).

Mackay, D. Shiu, W.Y. Ma, K.C. and Lee, S.C. (2010a) Handbook of physical-chemical properties and environmental fate for organic chemicals, Vol. 1, Introduction and hydrocarbons. CRC Pressed.

Mackay, D. Shiu, W.Y. Ma, K.C. and Lee, S.C. (2010b) Handbook of physical-chemical properties and environmental fate for organic chemicals, Vol. 2, Halogenated hydrocarbons. CRC Pressed. 
Mackay, D. Shiu, W.Y. Ma, K.C. and Lee, S.C. (2010c) Handbook of physical-chemical properties and environmental fate for organic chemicals, Vol. 3, Oxygen containing compounds. CRC Pressed.

Mackay, D. Shiu, W.Y. Ma, K.C. and Lee, S.C. (2010d) Handbook of physical-chemical properties and environmental fate for organic chemicals, Vol. 4, Nitrogen and sulfur containing compounds and pesticides. CRC Pressed.

Mitragotri, S. (2002) A theoretical analysis of permeation of small hydrophobic solutes across the stratum corneum based on scaled particle theory, J. Pharm. Sci., 91, 744-752.

Morawska, L. Afshari, A. Bae, G.N. Buonanno, G. Chao, C.Y.H. Hanninen, O. Hofmann, W. Isaxon, C. Jayaratne, E.R. Pasanen, P. Salthammer, T. Waring, M. and Wierzbicka, A. (2013) Indoor aerosols: from personal exposure to risk assessment, Indoor Air, 23, 462-487.

Moreau-Guigon, E. and Chevreuil, M. (2014) Human exposure to endocrine disruptors via ambient air: An unknown health risk, Arch. Mal. Prof. Environ., 75, 74-81.

Morrison, G. C. Weschler, C. J. and Bekö, G. (2016) Dermal uptake directly from air under transient conditions: advances in modeling and comparisons with experimental results for human subjects, Indoor air, 26, 913-924.

Morrison, G.C. Weschler, C.J. Bekö, G. Koch, H.M. Salthammer, T. Schripp, T. Toftum, J. and Clausen, G. (2016) Role of clothing in both accelerating and impeding dermal absorption of airborne SVOCs, J. Expos. Sci. Environ. Epidemiol., 26, 113-118.

NHANES (2015) Fourth National Report on Human Exposure to Environmental Chemicals. US Department of Health and Human and Service. Updated tables, February 2015. Center for Disease Control and Prevention. 
519 Pandrangi, L.S. and Morrison, G.C. (2008) Ozone interactions with human hair: Ozone uptake rates and product formation, Atmos. Environ., 42, 5079-5089.

Pankow, J.F. (1998) Further discussion of the octanol/air partition coefficient K-oa as a correlating parameter for gas/particle partitioning coefficients, Atmos. Environ., 32, 14931497.

Piotrowski, J.K. (1971) Evaluation of exposure to phenol: absorption of phenol vapour in the lungs and through the skin and excretion of phenol in urine, Brit. J. Ind. Med., 28, 172-178.

Pitz, M. Cyrys, J. Karg, E. Wiedensohler, A. Wichmann, H.E. and Heinrich, J. (2003) Variability of apparent particle density of an urban aerosol, Environ. Sci. Technol., 37(19), $4336-4342$.

Rubin, B.S. (2011) Bisphenol A: An endocrine disruptor with widespread exposure and multiple effects, J. Steroid Biochem., 127, 27-34.

Rudel, R. Dodson, R. Perovich, L. Morello-Frosch, R. Camann, D. Zuniga, M. Yau, A. Just, A. and Brody, J. (2010) Semivolatile endocrine-disrupting compounds in paired indoor and outdoor air in two northern California communities, Environ. Sci. Technol., 44, 6583-6590.

Rudel, R. Camann, D. Spengler, J. Korn, L. and Brody, J. (2003) Phthalates, alkylphenols, pesticides, polybrominated diphenyl ethers, and other endocrine-disrupting compounds in indoor air and dust, Environ. Sci. Technol., 37(20), 4543-4553.

Sabaterie, N. Kairo, C. and Zeghnoun, A. (2013) Body surface area in the French population: A proposed distribution for health risk assessments, Environ. Risque Sante, 12, 397-407.

Salthammer, T. and Schripp, T. (2015) Application of the Junge- and Pankow-equation for estimating indoor gas/particle distribution and exposure to SVOCs, Atmos. Environ., 106, 
542 Schossler, P. Schripp, T. Salthammer, T. and Bahadir, M. (2011) Beyond phthalates: Gas 543 phase concentrations and modeled gas/particle distribution of modern plasticizers, Sci. Total 544 Environ., 409, 4031-4038.

545 Shi, S. and Zhao, B. (2015) Estimating indoor semi-volatile organic compounds (SVOCs) 546 associated with settled dust by an integrated kinetic model accounting for aerosol dynamics, 547 Atmos. Environ., 107, 52-61.

548 Tamas, G. Weschler, C.J. Bako-Biro, Z. Wyon, D.P. and Strom-Tejsen, P. (2006) Factors 549 affecting ozone removal rates in a simulated aircraft cabin environment, Atmos. Environ., 40, $550 \quad 6122-6133$.

551 Tanguy, J. Zeghnoun, A. and Dor, F. (2007) Description of body weight according to sex and 552 age in the French population, Environ. Risque Sante, 6, 179-187.

553 Turpin, B.J. and Lim, H.J. (2001) Species contributions to PM2.5 mass concentrations: 554 Revisiting common assumptions for estimating organic mass, Aerosol Sci. Tech., 35, 602555610.

556 US EPA (2013) Estimation Program Interface (EPI) Suite (last updated on 15.3.2013, Version 557 EPI 4.11).

558 Weschler, C.J. Bekö, G. Koch, H.M. Salthammer, T. Schripp, T. Toftum, J. and Clausen, G. 559 (2015) Transdermal Uptake of Diethyl Phthalate and Di (n-butyl) Phthalate Directly from Air: 560 Experimental Verification, Environ. Health Persp., 1-6.

561 Weschler, C.J. and Nazaroff, W.W. (2014) Dermal Uptake of Organic Vapors Commonly 562 Found in Indoor Air, Environ. Sci. Technol., 48, 1230-1237. 
563 Weschler, C.J. and Nazaroff, W.W. (2012) SVOC exposure indoors: fresh look at dermal 564 pathways, Indoor Air, 22, 356-377.

565 Weschler, C.J. and Nazaroff, W.W. (2010) SVOC partitioning between the gas phase and 566 settled dust indoors, Atmos. Environ., 44, 3609-3620.

567 Weschler, C.J. and Nazaroff, W.W. (2008) Semivolatile organic compounds in indoor 568 environments, Atmos. Environ., 42, 9018-9040.

569 Wilson, N.K. Chuang, J.C. Lyu, C. Menton, R. and Morgan, M.K. (2003) Aggregate 570 exposures of nine preschool children to persistent organic pollutants at day care and at home, 571 J. Expo. Anal. Environ. Epidemiol., 13, 187-202.

572 Zaganas, I. Kapetanaki, S. Mastorodemos, V. Kanavouras, K. Colosio, C. Wilks, M.F. and 573 Tsatsakis, A.M. (2013) Linking pesticide exposure and dementia: What is the evidence? 574 Toxicology, 307, 3-11.

575 Zeghnoun, A. and Dor, F. (2010) Description of space-time-budget and exposure assessment 576 of the French population in the home, Report (in French), Institut de veille sanitaire577 Observatoire de la qualité de l'air intérieur, 37 pp. (available online: 578 http://www.oqai.fr/userdata/documents/298_InVS_OQAI_BET_Logements_2010_Internet.pdf). 